\title{
Analysis of the Quality of Digital Library Services in DKI Jakarta
}

\author{
Aditya ${ }^{1}$, Retnowati WD Tuti ${ }^{2, *}$ \\ 1,2 Muhammadiyah University Jakarta, Kota Tangerang Selatan, Banten 15419, Indonesia \\ 1 adhietdki@ymail.com ; ${ }^{2}$ retnowatiwdtuti@yahoo.com \\ * corresponding author
}

\section{ARTICLE INFO}

\section{Article history}

Received 2020-12-31

Revised 2020-12-30

Accepted 2020-11-26

\section{Keywords}

Mental revolution, magrib recitation movement policy

\begin{abstract}
This research was conducted to analyze in depth how the quality of iJakarta digital library services in the Jakarta Provincial Library and Archives Service. The theory analysis is a theory of five dimensions of service quality consisting of :Tangible, Reliability, Responsiveness, Assurance, and Empathy. The method in this study useds a qualitative approach with descriptive methods Data collection techniques are done through observation, interviews and documentation. Data validity test uses Triangulation. The results showed that the quality of digital library services in the DKI Jakarta Provincial Library and Archives Service has not been fully said to be good. Collection of books in the Department of Library and Archives of the DKI Jakarta Provincial Government is incomplete, iJakarta applications sometimes experience errors/bugs, other than that the download time of books to be read is relatively long, can reach 5 minutes per book, Inadequate complaints channel for users I users who want to convey the problem, Handling of complaints is still very dependent on PT.Aksaramaya. This can hinder readers/visitors who need a quick complaint handling because the Library and Archives Service must first coordinate with PT.Aksaramaya and There is no audio book facility that should be available for persons with disabilities from the blind group.
\end{abstract}

\section{INTRODUCTING}

In the era of digitalization, the development of digital technology has brought about changes in lifestyles and the needs of the people, especially the people of Jakarta in accessing information. According to Farooq at al evolution of digitalizations has empowered the customer, this evolution in digitalization demands from companies to change themselves as the needs of their customer.

DKI Jakarta Province as the center of government with large internet users must support the drivers of digital content development to fill the public space vacancy so that people get interesting content related to being involved in the development of public infrastructure and facilities in the digital realm with Regional Work Units that support serving the community in the field of library and archives, namely the Jakarta Provincial Library and Archive Service, which has a vision: "The realization of a transparent and accountable information service to fulfill the information applicant's rights in accordance with the provisions of the legislation requested".

One of the matters which is the duty of Library and Archives Service is the Library. The DKI Jakarta Provincial Public Library as a place of service to the community to obtain information and independent learning to be able to improve public knowledge and education. As a center of information and science, the library does not only pay attention to physical facilities limited to buildings and printed books to meet the needs of its stakeholders. Quality and modern libraries have the duties and functions to search, collect, organize, document and present information to users both in printed form and in electronic form so that customer satisfaction is achieved.

But in reality, the quality of service at iJakarta is still less like: the number of book collections owned by iJakarta digital library is quite large and varied. Until now there were 15,577 titles consisting of 10,141 titles in 2015, 2,795 titles in 2016, 1,418 titles in 2017, 657 titles in 2018 and 569 titles in 2019 and 566 titles in the book (Library and Archive Service of DKI Jakarta Province, 2019). But unfortunately 
the large number of books has not been accompanied by the large frequency of visits and the number of borrowing iJakarta Digital Library collections.

If you look at the number of visitors to the iJakarta digital library from the monthly report table of the Head of the DKI Jakarta Provincial Library and Archives (Dispusip) in 2019, then the trend of library visitors is likely to stagnate or decline. This can be seen from the graph below:

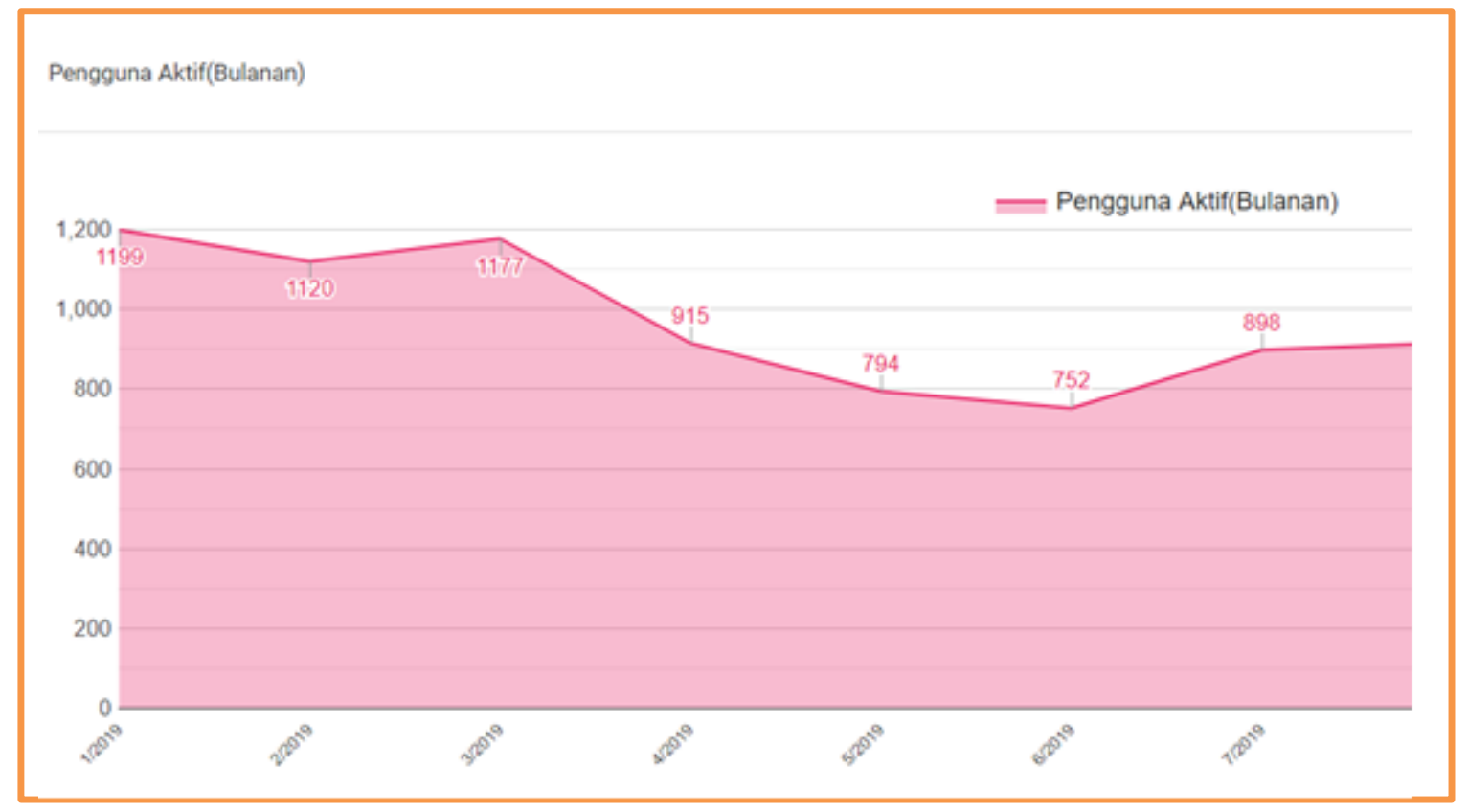

Figure 1. Trends in the Number of Visitors Period January - July 2019

Based on the graph above, it can be justified that there is no consistency in the number of library visitors, even the trend tends to decrease. In January there were 1,199 active users, in February 1,120 visitors, in March it had increased to 1,177 visitors, but in April it dropped quite dramatically to 915 visitors, in May it fell to 794 visitors, in June it also dropped to 752 visitors and in in July the number of visitors rose to 898 (DKI Jakarta Provincial Library and Archives Service, 2019).

The instability of the frequency of visits from the number of book loans each month shows that there is still a lack of Quality of Service in the iJakarta Digital Library. Library visitors as recipients of services have a dominant role in determining the assessment of library performance as a service provider. For this reason, the public, especially visitors to the iJakarta Digital Library as service recipients must have access to a system of policies / regulations and evaluation of iJakarta Digital Library services.

From the above background, it can be seen that the purpose of this writing is to Analyze the Quality of Digital Library Services in the Library and Archives Service in DKI Jakarta Community Education

Research conducted by Latif The purpose of this study is to develop and validate the HiEduQual (High Quality Education Services) construct to measure higher levels of service quality of educational institutions. First, existing studies only focus on students for the generation of questionnaire items. This study considers other stakeholders to develop measures for HE quality of services provided to students. Second, existing research ignores that fact how service levels in education have changed over time, and third, the current study finds leadership as a significant quality dimension in HE. Limitations and future research directions are discussed.

According to research conducted by Ozbekler The aim of this study is to examine the level of quality felt by logistic service providers in terms of the triple bottom line approach and to determine the relationship between them for sustainable competition. In line with exploratory methods, factor analysis 
is used with the aim of finding a new scale for the literature on testing the relationship between perceived quality and corporate sustainability in a competitive framework.

Purwanto says Citizens' perceptions of the quality of OGD services are a more important driver of trust in OGD. Regarding the practical contribution of this research, open data policymakers must be aware that citizens' perceptions about data quality can be greatly improved when appropriate human services are provided (eg, designated civil servants who offer support or assistance to data users) in addition to providing portal functionality OGD (e.g., visualization and comparison tool data)

While according to Arias This investigation aims to synthesize related work in the area of eGovernment service quality. This method is based on a qualitative approach in two steps: 1) Identification of articles related to the quality of e-Government services and 2) Analysis of the content of this article. The findings show an integrative view of 48 articles, classified in 28 investigations, which propose a competitive model to assess the quality of e-Government services as the final dependent variable consisting of different independent variables. The relevance of this work depends on the integrative view of these models that almost did not exist before in the literature.

Digital governance is often seen as a driver or even a driver of public administration transformation, with the aim of creating public value. This case illustrates how the development of electronic services can highlight changes in social values, and the challenges that arise when trying to defend them change social values.

Partap says Due to impact of Information and Communication Technology (ICT) and changing needs of users, libraries have to force to shift from manual to automated environment. Users now want quality services within shortest possible time. Libraries have to assess its services from the user's point of view. It is the user, who can judge the services better provided by the concerned library.

Ahmad et al quality of service (QoS) is one of the most important factors and is a major issue on the research agenda for electronic service.

The majority of libraries cannot be accessed by people with disabilities outside the main entrance of the library. The biggest challenge is the absence of a variety of media information for people with visual and hearing impairments. Also, these findings reveal that library staff lack sufficient knowledge about issues relating to persons with disabilities and their right to access information.

Santos During the past two decades, service quality has become a popular area of academic investigation, and has become recognized as a key factor in differentiating service product and building competitive advantage (Ennew et al.,1993; Zeithaml et al., 1996). The service revolution has increasingly been an information revolution and information service is the highest growth area in the sector.

The results show that the perceived service quality level exceeds the level that users can accept at the minimum service and desired service. Specifically, users are satisfied with the services provided. The results of this study serve as a guide for effective decision making by libraries in administration and allocation of resources to ensure the achievement of the library's vision and mission.

The concept of e-government service quality has eight dimensions that contribute: system quality, reliability, security, accessibility, information quality, service capability, interactivity, and responsiveness. The perceived service value is a strong mediator between service quality and intention to use citizens continuously. The intention to use is a consequence of service quality, service value, and satisfaction.

Delivery of public services is fully manual with social divisions and is a playground for people and corrupt practices. This calls for empirical exploration to assess and compare user perceptions of conventional manual public service delivery and public electronic service delivery. The purpose of this research is to enable administrators and policy makers to pay close attention to these issues, which can help them in redesigning public services for an effective, efficient, economical, and equitable government.

Departing from the assumption that the involvement of the private sector increases efficiency and effectiveness, many Western governments create public-private partnerships (PPP) for the delivery of 
public services and public infrastructure. However, it is said that quality might be at stake when, in seeking financial optimization, private companies take over responsibility.

Service quality in Local Public Administration can be used for proper analysis, as well as estimates regarding the evolution of the quality level in the services mentioned or to make conclusions and measure plans regarding improving service quality in Local Public Administration.

The public service website run by the South Jakarta Municipality is planned to integrate services into the process of obtaining civil identity cards, city planning permits, tourism, population, building permits and others. The e-Government application using information technology in the South Jakarta Municipality office still has many obstacles, namely human resources, the budget used and infrastructure.

Rorim says Library has a very important role in the learning process, both for primary, secondary and higher education level. So the main function of the library is to serve students and educators or users of outside education in finding a reference to a sub-field of science or science they are studying. For that, a library that can serve, have references required by the user, can read books and learn in library room.

The purpose of this study is to analyze the quality of service to residents of Rawa Rawa Bebek and find and apply a service model suitable for residents of Rusunawa. Knife analysis of the quality of Rusunawa Rawa Bebek services using sizes: Convenience; Reliability; Personal Attention; Citizen Influence; .airness; Problem-Solving Approach; Fiscal Responsibility and Security. While the Research Method used is the Descriptive Method with a Qualitative Approach. Research Results Services in Rusuuwa have not been applied wholeheartedly.

According to Parasuraman, Zethitml and Berry Service quality is a reflection of consumers' evaluative perceptions of services received at any given time. Service quality is determined based on the level of importance in the service dimension. Quality of service is determined by two things, namely: expected service and acceptable service. The main dimensions that are the main factors determining the quality of service are as follows:

1. Reliability, which is the ability to deliver the promised service reliably and accurately.

2. Responsiveness (Responsiveness), namely the willingness to help consumers by providing services that are fast and appropriate.

3. Assurance. That includes knowledge, abilities, and politeness or goodness of the person and the ability to gain trust and desire.

4. Empathy (Empathy), which includes maintaining and providing a level of attention individually or personally to the needs of consumers.

5. Tangible (Direct Proof), which includes physical facilities, equipment or equipment, prices, and appearance of written personnel and materials.

\section{METHOD}

The approach used in this study is a qualitative approach, so that social phenomena that cannot be explained quantitatively can be analyzed. Data analysis uses the Miles and Huberman analysis model. The data analysis used is based on Miles and Huberman, an interactive model that internalizes the steps in data analysis activities with several sections including: data collection, data reduction, data presentation, and drawing conclusions or verification. This process continues throughout the research, even before the research data is actually collected. Data collection techniques are done through observation, interviews and documentation. Observation is carried out by observing the registration process until the disbursement. Interviews are conducted openly using the Interview Guidelines that have been prepared in accordance with the dimensions in the measurement of the Quality of Digital Library Services, Documentation including, among others, the Governor Regulation of the Jakarta Special Capital Region Number 2 Year 2016 About the Electronic Library of I-Jakarta, Informants are selected purposively, namely selected people parents and students and school staff / teachers who have adequate knowledge of the Library Service. Data validity test uses Triangulation to obtain data validity, so the information obtained is more valid. 


\section{RESULTS AND DISCUSSION}

The tangible dimension in this study is explained about what iJakarta users see in using the iJakarta application in terms of appearance, features, ease of downloading and installing applications as well as the visual display of book titles that can be borrowed at iJakarta digital library services.

Based on the results of observations and in-depth interviews, The informant stated the following "ijakarta display is ok, only for the bored appearance does not need to be improved, compared to conventional libraries it is easier in digital libraries to search for books, there is no need to add menus, because there are still many books that are not yet in the ijakarta application, still incomplete" .

The iJakarta application in terms of menus, features and book titles in iJakarta is in accordance with what is desired, but features need to be added for people with visual impairments, by adding audiobooks, videobooks and adding the title of the book is that there are many queues, or best sellers, so the user does not need to wait a long time to get the book readings.

The display for reading the ebook is better on a PC or Notebook which has a larger screen size, but on a mobile phone it is also quite comfortable, as long as the specifications are not below those already mentioned. The menu display is quite good with a color dominated by the distinctive orange color of Jakarta, and the placement of the title of the book and easy book search as seen in the documentation in the form of the image below:

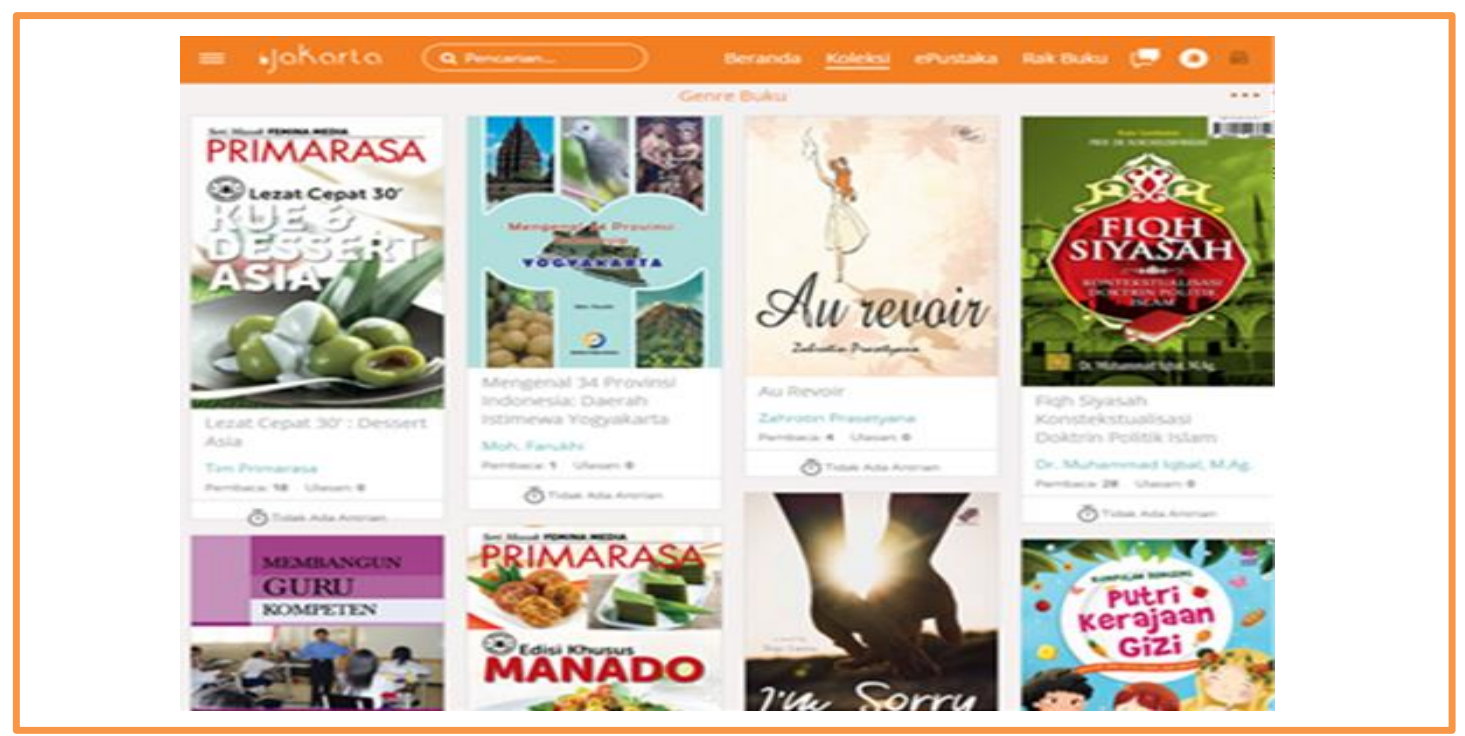

Figure 2 Display and Collection of iJakarta (Digital Turnover)

From the picture above it appears that in the iJakarta digital library seen from aspects of tangible dimensions or the form of electronic display services is quite good because: 1) The form of digital books that can be read can follow the amount of the screen used. The larger the screen size used, the digital book display will also be bigger; 2) App design is attractive, eye catching and fun for users of all ages and professions; 3) Already available in 3 platforms, namely android, iOS and website; 4) Easy installation and registration process.

\section{Reliability}

The Reliability dimension in an effort to find out the quality of digital library services in the DKI Jakarta Provincial Library and Archives Service can be measured by the number of library visitors and the minimum number of complaints from the use of ijakarta digital library services.

Based on the results of in-depth interviews, it can be justified that the performance of service applications has not been so good. That is because sometimes the ijakarta application experiences bugs, the download duration can also be said to be not good because it is relatively long (3-5 minutes). When the network is bad it can take even longer.

Meanwhile, the observation found that if the application is installed using a PC / Laptop device 
or an older website version, this is confirmed by the application developer that for the website version there is application maintenance. But according to the researchers, this is due to the use of similar digital library applications that have been done by PT Aksaramaya, but there is no server addition. Until now the ijakarta application still uses the PT Aksaramaya server, the new application is submitted until the collaboration period ends in accordance with the clause in the Cooperation Agreement Letter.

\section{Responsiveness}

The responsiveness dimension is a very dynamic dimension. In a simple manner, responsiveness is defined as willingness to help customers and provide prompt service. In this dimension service personnel must respond quickly and be responsive to complaints submitted by service users. The dimension of responsiveness is very important for a public service institution, because the dimension can determine the satisfaction of service users. To measure the quality of service dimensions of responsiveness in digital library services the Library and Archives Service can be seen from the number of complaints that are compared to the number of users / users who borrow.

Based on the results of in-depth interviews as described above, it can be analyzed that some users / users have no problems in using the iJakarta application, but there are still informants who actually want to submit complaints but do not know the channels and mechanisms of complaints in a concrete manner. This needs to be addressed seriously by the manager, especially PT. Aksaramaya.

On the other hand, based on observations, complaints from users / users of various types, but the most complained of is borrowing books using a PC that is still slow. This complaint was immediately responded by PT. Aksaramaya to users by giving suggestions for using other media besides using the ijakarta website, because the website version is under application development. From the results of the interview and observation above.

\section{Assurance}

The Assurance dimension is a very important dimension in seeing a quality of service. Assurance is a guarantee on time in service, guarantee of cost certainty in service, and guarantee legality in service. Assurance includes knowledge, ability, courtesy, free from danger, risk and doubt. Based on the indicators presented by the experts above, then to measure the quality of digital library services in the Library and Archives Service, the indicator used is a guarantee for publishers that books cannot be downloaded by the user / user, for the user / user that guarantees equal rights and service obligations and guarantees are free of charge.

The results of the in-depth interview described above show the fact that from the assurance dimension, there are guarantees that protect the parties, especially book publishers. This is evidenced by the existence of Digital Rights Management (DRM). And this is reinforced by the agreement between the issuer and the manager to both protect and fulfill their respective rights and obligations. In addition, it is also accommodated by a system that limits the user to just be able to read and not be able to download the book.

On the other hand, based on observations, the ebook in the iJakarta application can only be seen or read only, because this ebook is given security with the name DRM or Digital Rights Management. The download process is only in the application, so the borrower cannot have a soft copy of the ebook. This is an agreement between the publisher and the developer, so that the publisher's copyright is guaranteed. So the publisher does not need to worry that his work can be duplicated by others without the person buying the ebook. Guarantees for the results of the download of the book are not sent wrong are also accommodated by the iJakarta application so that users are guaranteed not to run out of opportunities to borrow books for a maximum of 1 user a maximum of 3 books. In addition, there is also a free guarantee for the book lending service, and there are no fines because the book will return automatically for 3 calendar days, even though the user forgot to return it.

Empathy

The empathy dimension includes ease in making good communication relationships, personal attention and understanding customer needs. The quality of service in this empathy dimension can be seen from several aspects including: providing wholehearted services, special treatment to persons with 
disabilities, and the presence or absence of discriminatory practices in iJakarta digital library services.

Based on the results of in-depth interviews, it can be analyzed that from the empathy dimension, the quality of digital library services in the DKI Jakarta Library and Archives Service is not very good. This justification is based on 2 things: 1) Handling of complaints is still very dependent on PT. Aksaramaya. This can prevent users who need to handle complaints quickly because Dispusip must coordinate first to PT. Aksaramaya; 2) There is no audio book facility that should be available for persons with disabilities from the blind group.

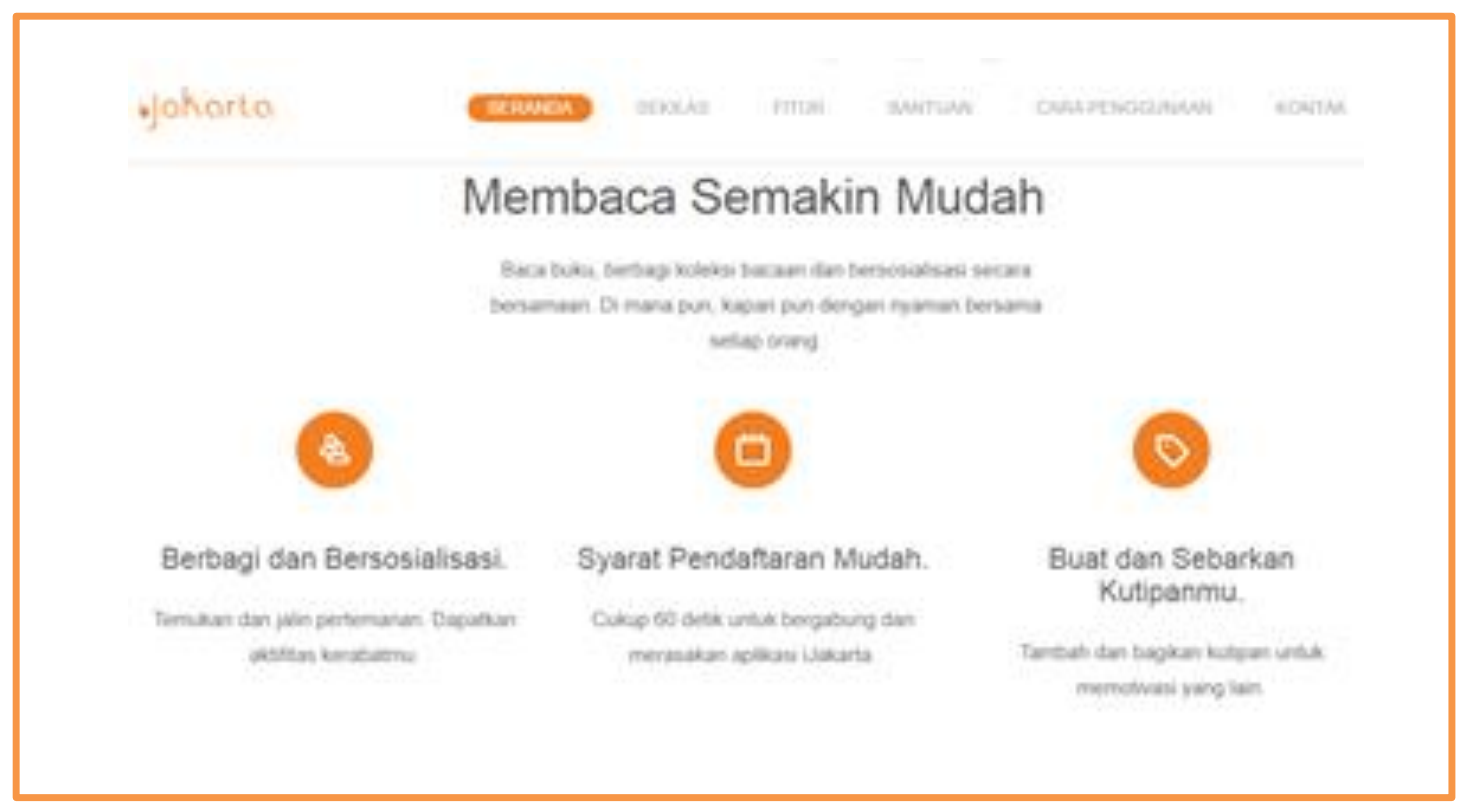

Figure 3. ease of registering

Based on the meaning of the picture above, it can be seen that the ease of guarantee in registering iJakarta is very easy, the community only needs 60 seconds to register.

From the results of observations, it is related to the Cooperation Agreement (PKS) Number 16 of 2016, that the management of the iJakarta application is still entirely by the PT. Aaksaramaya, so that including the handling of complaints to this day is still managed by Aksaramaya. The next aspect to be elaborated from the empathy dimension is special treatment for persons with disabilities. Persons with disabilities other than the blind can still use the iJakarta digital library service facilities, but there are no features available for persons with visual impairments. However, in the future an audiobook feature will be made, where borrowed books can sound the same as we read the book.

Here is a display platform that supports iJakarta :

\section{0}

Figure 3. Display Platform

\section{CONCLUSION}

Based on the research results above, it can be said that the quality of digital library services in the DKI Jakarta Library and Archives Service is of poor quality, as illustrated by each dimension: Tangible, the public can already feel the digital library application, the services provided in the iJakarta application have also a lot, but iJakarta does not yet support services to people with disabilities. Reliability, service is not so good. That is because sometimes the ijakarta application experiences bugs even more so the government has not yet upgraded the service by adding servers for repairs. Responsiveness, there is no 
place for the community to be able to make complaints about iJakarta services. Assurance, iJakarta applications can only be seen or read only, because this ebook is given security with the name DRM or Digital Rights Management. The download process is only in the application, so the borrower cannot have a soft copy of the ebook. Empathy. iJakarta application management is still fully by the PT. Aksaramaya, so that including the handling of complaints to this day is still managed by Aksaramaya. The next aspect to be elaborated from the empathy dimension is special treatment for persons with disabilities. Persons with disabilities other than the blind can still use the iJakarta digital library service facilities, but there are no features available for persons with visual impairments.

Meanwhile, there are things that are hampering, namely: 1) Collection of books in the Jakarta Provincial Library and Archives Service is incomplete; 2) iJakarta applications sometimes experience errors / bugs, other than that the download time of books to be read is relatively long, can reach 5 minutes per book; 3) Inadequate complaints channel for users / users who want to convey the problem; 4) Handling of complaints is still very dependent on PT. Aksaramaya. This can prevent users who need to handle complaints quickly because Dispusip must coordinate first to PT. Aksaramaya; and 5) There is no audio book facility that should be available for persons with disabilities from the blind group.

\section{Suggestion}

Based on the above conclusions, it is recommended:

1). Added Number and Title of book collections

2). A high quality iJakarta application should be provided so that errors / bugs are not frequent

3). Complaints channel held for users

4). Handling of complaints is still very dependent on PT. Aksaramaya

5). Improved Audio Book Facilities that should be available for people with disabilities from the blind group.

\section{Acknowledgments}

Thank you to Kemensitekdikti who has provided financial assistance through the 2019 Masters Thesis Grant to students for the completion of their Scientific Work .Acknowledgment

\section{REFERENCES}

M. Farooq et al., "SERVICE QUALITY ANALYSIS OF PRIVATE UNIVERSITIES LIBRARIES IN MALAYSIA IN THE ERA OF TRANSFORMATIVE MARKETING," Int. J. Qual. Res., vol. 13, no. 2, pp. 269-284, Jun. 2019, doi: 10.24874/IJQR13.02-02.

K. F. Latif, I. Latif, U. F. Sahibzada, and M. Ullah, "Total Quality Management \& Business Excellence In search of quality: measuring Higher Education Service Quality ( HiEduQual )," Total Qual. Manag. Bus. Excell., vol. 3363, no. June, pp. 0-24, 2017, doi: 10.1080/14783363.2017.1338133.

T. M. Ozbekler, "Analysing the importance of sustainability-oriented service quality in competition environment," Bussines Strategy Environ., no. October 2019, pp. 1-13, 2020, doi: 10.1002/bse.2449.

A. Purwanto and M. Janssen, "Citizens' Trust in Open Government Data A Quantitative Study about the Effects of Data Quality, System Quality and Service Quality," pp. 310-318.

M. I. Arias and A. C. G. Maçada, "Digital government for E-government service quality: A literature review," ACM Int. Conf. Proceeding Ser., pp. 7-17, 2018, doi: 10.1145/3209415.3209422.

I. Lindgren and A. F. van Veenstra, "Digital government transformation," pp. 1-6, 2018, doi: $10.1145 / 3209281.3209302$.

B. Partap, “A Review of Service Quality Assessment of Library and Information Centres," p. 19.

M. Ahmad, J. Abawajy, and T. Kim, "Service Quality Assessment in Provision of Library Services," in U- and E-Service, Science and Technology, vol. 264, T. Kim, H. Adeli, J. Ma, W. Fang, B.-H. Kang, B. Park, F. E. Sandnes, and K. C. Lee, Eds. Berlin, Heidelberg: Springer Berlin Heidelberg, 2011, pp. 83-92. 
D. A. Ayoung, F. N. A. Baada, and P. Baayel, "Access to library services and facilities by persons with disability: Insights from academic libraries in Ghana," J. Librariansh. Inf. Sci., 2020, doi: 10.1177/0961000620917723.

J. Santos, "E-service quality: a model of virtual service quality dimensions," Manag. Serv. Qual. Int. J., vol. 13, no. 3, pp. 233-246, Jun. 2003, doi: 10.1108/09604520310476490.

S. M. Dahan, M. Y. Taib, N. M. Zainudin, and F. Ismail, "Surveying Users' Perception of Academic Library Services Quality: A Case Study in Universiti Malaysia Pahang (UMP) Library," J. Acad. Librariansh., vol. 42, no. 1, pp. 38-43, 2016, doi: 10.1016/j.acalib.2015.10.006.

Y. Li and H. Shang, "Information \& Management Service quality, perceived value, and citizens , continuous-use intention regarding e-government: Empirical evidence from China," Inf. Manage., vol. 57, no. 3, p. 103197, 2020, doi: 10.1016/j.im.2019.103197.

V. Dalal and S. Sharma, "Redesigning Public Services Delivery: A Comparative Study of Delivery of Manual Conventional Public Services and Delivery of Public E-Services," IUP J. Supply Chain Manag., vol. XVI, no. 1, pp. 37-51, 2019.

L. Huberts, Quality of Governance. 2020.

M. A. Titu and A. Bucur, "Models for quality analysis of services in the local public administration," Qual. Quant., vol. 50, no. 2, pp. 921-936, 2016, doi: 10.1007/s11135-015-0183-3.

F. Ratih Wulandari and Y. Tirtariandi El Anshori, "Optimizing Public Service Through E-Gov Services (the Case of Public Service in South Jakarta Munici Pality)," J. Gov. Polit., vol. 3, no. 2, pp. 369390, 2012, doi: 10.18196/jgp.2012.0021.

R. Panday, "SERVICE QUALITY OF LIBRARY TOWARD AN INTERNATIONAL COLLEGE QUALITY," INA-Rxiv, preprint, Aug. 2018. doi: 10.31227/osf.io/34kyf.

R. W. D. Tuti, "Service Quality ( Servqual ) Toward Rawa Bebek Flats Residents In DKI Jakarta," vol. 10, no. 3, pp. 223-241, 2019.

a Parasuraman, V. a Zeithaml, and L. L. Berry, "SERQUAL: A Multiple-Item scale for Measuring Consumer Perceptions of Service Quality," Journal of Retailing. 1988, doi: 10.1016/S01482963(99)00084-3.

M. Miles and A. Huberman, "Miles and Huberman Chapter 2," in Qualitative Data Analysis, 1994.

L. J. Prof. Dr. M. A. (2000) Moleong, “Metode Penelitian,” Penelitian, 2000, doi: 10.1021/o17029646. 